\title{
PENINGKATAN PERTUMBUHAN Daphnia sp. MENGGUNAKAN MEDIA KOTORAN AYAM YANG DICAMPUR DEDAK PADI DENGAN KONSENTRASI BERBEDA
}

\section{INCREASE THE GROWTH OF Daphnia sp. USE MIXED OF CHICKCEN MANURE AND RICE BRAN CULTURE MEDIA WITH DIFFERENT CONCENTRATION}

\author{
Putri Dara Yunda ${ }^{1 *}$, Sri Murwani', Endang Linirin Widiastuti ${ }^{1}$ \\ 1Jurusan Biologi FMIPA, Universitas Lampung \\ Jl. Prof. Dr. Sumantri Brojonegoro No. 1 Bandar Lampung 35145 \\ *e-mail : putridarayunda@gmail.com
}

\begin{abstract}
ABSTRAK
Penelitian ini bertujuan untuk mengetahui peningkatan populasi dan laju pertumbuhan populasi spesifik Daphnia sp. pada media kotoran ayam yang dicampur dedak padi dengan konsentrasi berbeda. Penelitian ini dilaksanakan di Laboratorium Biologi Molekuler II Fakultas Matematika dan IImu Pengetahuan Alam Universitas Lampung pada Bulan Desember 2014. Penelitian ini menggunakan Rancangan Acak Lengkap (RAL) terdiri dari 5 perlakuan yaitu P1 (kotoran ayam $100 \%$ ), P2 (dedak padi $100 \%$ ), P3 (kotoran ayam $75 \%$ + dedak padi $25 \%$ ), P4 (kotoran ayam $50 \%+$ dedak padi $50 \%$ ), dan P5 (kotoran ayam $25 \%$ + dedak padi $75 \%$ ) dengan pengulangan sebanyak 4 kali pada masing-masing perlakuan. Parameter yang diamati adalah kepadatan populasi, laju pertumbuhan populasi spesifik, dan kualitas air. Data dianalisis dengan analisis sidik ragam (ANOVA) dan dilanjutkan dengan uji Beda Nyata Terkecil (BNT) pada taraf $5 \%$. Hasil penelitian menunjukkan bahwa kepadatan tertinggi populasi Daphnia sp. adalah pada media campuran kotoran ayam $75 \%+$ dedak padi $25 \%$ yaitu dengan jumlah $970 \mathrm{ind} / \mathrm{L}$, sedangkan kepadatan populasi terendah yaitu pada media menggunakan dedak padi $100 \%$ sebesar $730 \mathrm{ind} / \mathrm{L}$. Media kultur terbaik adalah campuran kotoran ayam $75 \%$ + dedak padi $25 \%$ dengan laju pertumbuhan populasi spesifik tertinggi Daphnia sp. yaitu sebesar $43,11 \% /$ hari.
\end{abstract}

Kata kunci: Daphnia sp., dedak padi, kepadatan populasi, kotoran ayam

\begin{abstract}
This aims of the study was to determine the increase in population size and the population growth rate of Daphnia sp. on chicken manure media mixed with rice bran with different concentrations. This research had been done in Aquatic Laboratory of Faculty of Mathematics and Natural Sciences, University of Lampung on December 2014. This study used a completely randomized design (CRD), with five treatments, namely: P1 (100\% chicken manure), P2 (rice bran 100\%), P3 (chicken manure $75 \%+25 \%$ rice bran), P4 (chicken manure $50 \%+50 \%$ rice bran), and P5 (chicken manure $25 \%+$ $75 \%$ rice bran) with 4 replications. The observed parameters were the population density of Daphnia sp., a specific population growth rate, and water quality. Anova was used for analizing with $5 \%$ LSD. The results showed that the population density of Daphnia sp. of P3 treatment showed the highest population density of $970 \mathrm{ind} / \mathrm{L}$, while the lowest population density was showed by $\mathrm{P} 2$ with $730 \mathrm{ind} / \mathrm{L}$ from this study. The best quality of cultur media for Daphnia sp. was consisted of $75 \%$ chicken manure and $25 \%$ rice bran of growth rate of Daphnia sp. of $43.11 \% /$ day.
\end{abstract}

\section{Keywords : Daphnia sp., Rice bran, Population density, Chicken manure}

\section{Pendahuluan}

Dalam sistem budidaya perikanan, kegiatan pembenihan ikan sangat bergantung pada ketersediaan pakan alami untuk mendukung pertumbuhan dan kecukupan gizi ikan. Pakan alami sangat diperlukan karena menunjang kelangsungan hidup benih ikan, dari saat 
telur ikan baru menetas sampai makanan cadangan di dalam tubuhnya habis. Pada fase ini benih ikan membutuhkan pakan yang sesuai dengan bukaan mulutnya.

Pemberian pakan alami biasanya menggunakan jenis renik yang hidup di perairan berupa fitoplankton maupun zooplankton (Djarijah, 1995). Hal ini karena pakan alami memiliki ukuran yang sesuai dengan bukaan mulut ikan serta gerakan yang ditimbulkan dapat merangsang larva ikan untuk mengejar dan memakannya (Casmuji, 2002). Di samping itu, fitoplankton dan zooplankton dapat berkembangbiak dalam waktu yang relatif singkat yaitu pada umur 4-6 hari (Mokoginta, 2003).

Salah satu jenis zooplankton yang berkembangbiak relatif singkat dan mudah dibudidayakan adalah Daphnia sp. Menurut Sayuti (2003) pada musim pemijahan ikan, Daphnia sp. banyak dicari pembudidaya ikan untuk dimanfaatkan sebagai pakan larva, karena kandungan nutrisi yang tinggi. Kandungan nutrisi yang dimiliki Daphnia sp. berdasarkan hasil analisis proksimat adalah 94,04\% air, 2,98 \% protein, 0,43 \% lemak, 0,16\% serat yang dibutuhkan larva ikan untuk pertumbuhannya, sehingga perlu dilakukan kultur Daphnia sp. sebagai pakan alami untuk benih ikan air tawar (Hadadi, 2004).
Kultur Daphnia sp. telah banyak dilakukan melalui berbagai macam teknik dengan penambahan bahan nutrisi atau pakan yang berbeda, misalnya penelitian Sulasingkin (2003) dengan menggunakan kotoran ayam, penelitian Mubarak (2009) dengan penambahan bekatul, dan penelitian yang dilakukan Arief (2012) dengan penambahan bungkil kelapa. Bahan organik tersebut memiliki nutrisi yang tinggi dan dapat dimanfaatkan oleh Daphnia sp. dalam berkembangbiak. Kandungan nutrisi yang terdapat dalam pakan sangat berpengaruh terhadap hasil panen, karena nutrisi yang baik dapat memacu pertumbuhan yang baik pula (Makmur, 2004).

Penggunaan kotoran ayam sebagai media kultur Daphnia sp. memberikan pertumbuhan populasi yang baik karena memiliki kandungan bahan organik yang tinggi dengan protein $10-11 \%$. Dedak padi juga mempunyai bahan organik yang relatif tinggi dengan kandungan protein $13 \%$. Selain kandungan protein yang tinggi dedak juga mudah diperoleh dibandingkan dengan kotoran ayam, karena produksi dedak padi di Indonesia cukup besar dan hanya terbatas pada pakan ternak saja padahal dedak dapat dimanfaatkan dengan lebih maksimal.

Untuk itu perlu dilakukan penelitian tentang pemanfaatan kotoran ayam yang dikombinasikan dengan dedak padi sebagai media kultur Daphnia sp. 
Disamping itu, peneltian ini bertujuan untuk mengetahui kombinasi campuran kotoran ayam dan dedak padi yang terbaik untuk kultur Daphnia sp.

\section{Bahan dan Metode}

Penelitian ini dilaksanakan pada bulan Desember 2014 bertempat di Laboratorium biologi molekuler II Jurusan Biologi Fakultas Matematika dan IImu Pengetahuan Alam Universitas Lampung. Alat yang digunakan selama penelitian adalah toples kaca dengan tinggi $25 \mathrm{~cm}$, diameter $14 \mathrm{~cm}$ sebanyak 20 unit yang dilengkapi dengan aerator untuk memasok oksigen terlarut agar kualitas lingkungan hidup Daphnia sp. terjaga. Alat-alat penunjang yang digunakan yaitu kain jaring sebagai penutup bagian atas toples kaca, timbangan dan alat sampling seperti cawan petri, gelas ukur dan pipet tetes, alat untuk mengukur kualitas air terdiri dari termometer yang digunakan untuk mengukur suhu pada media pemeliharaan, DO meter untuk mengukur jumlah oksigen terlarut pada media, kertas indikator ( $\mathrm{pH}$ stick) untuk mengukur $\mathrm{pH}$.

Bahan yang digunakan selama penelitian adalah kotoran ayam, dedak padi, bibit Daphnia sp. 800 ekor dan setiap wadah kultur diisi Daphnia sp. sebanyak 20 ekor/liter pada awal pemeliharaan kemudian diisi air tawar sebanyak 2 liter.
Penelitian ini menggunakan Racangan Acak Lengkap (RAL) dengan 5 perlakuan dan 4 ulangan yaitu :

Perlakuan 1: Pemberian kotoran ayam $100 \%(2,4 \mathrm{~g} / \mathrm{L})$ (Sulangsikin, 2003).

Perlakuan 2 : Pemberian dedak padi 100 $\%(2,4 \mathrm{~g} / \mathrm{L})$

Perlakuan 3 : Pemberian kotoran ayam 75 $\%(1,8 \mathrm{~g} / \mathrm{L})+$ dedak padi $25 \%$ $(0,6 \mathrm{~g} / \mathrm{L})$

Perlakuan 4 : Pemberian kotoran ayam 50 $\%(1,2 \mathrm{~g} / \mathrm{L})+$ dedak padi $50 \%$ $(1,2 \mathrm{~g} / \mathrm{L})$

Perlakuan 5 : Pemberian kotoran ayam 25 $\%(0,6 \mathrm{~g} / \mathrm{L})+$ dedak padi $75 \%$ $(1,8 \mathrm{~g} / \mathrm{L})$

Pemeliharaan Daphnia sp. dilakukan selama 13 hari. Pemberian pakan dilakukan pada hari pertama dan hari ke 7 . Sedangkan penghitungan jumlah Daphnia sp. dilakukan dua hari sekali dalam waktu 13 hari. Sampel air diambil sebanyak 100 $\mathrm{ml}$ dengan menggunakan gelas ukur. Sampel yang berada dalam gelas ukur dituangkan sedikit demi sedikit kedalam cawan petri, kemudian dihitung.

Laju pertumbuhan populasi spesifik Daphnia sp. dihitung dengan menggunakan rumus modifikasi Becker (1994) yaitu: 


$$
\mu=\frac{\text { LnNt }- \text { LnNo }}{t} \times 100 \%
$$

Keterangan :

$\mu \quad$ : Laju Pertumbuhan Populasi (\%/hari)

No : Kepadatan awal populasi (Ind/L)

$\mathrm{Nt}$ : Kepadatan akhir populasi (Ind/L)

t : Waktu (hari)

Pengukuran kualitas air, suhu, oksigen terlarut, $\mathrm{pH}$, dan ammonia dilakukan pada hari ke 0 , ke 6, dan hari ke 13. Parameter yang diamati dalam penelitian ini adalah kepadatan populasi Daphnia sp., laju pertumbuhan populasi spesifik, dan kualitas air.

\section{Hasil dan Pembahasan}

Kepadatan populasi Daphnia sp. tertinggi untuk semua perlakuan terjadi pada hari ke 9 (Gambar 1).

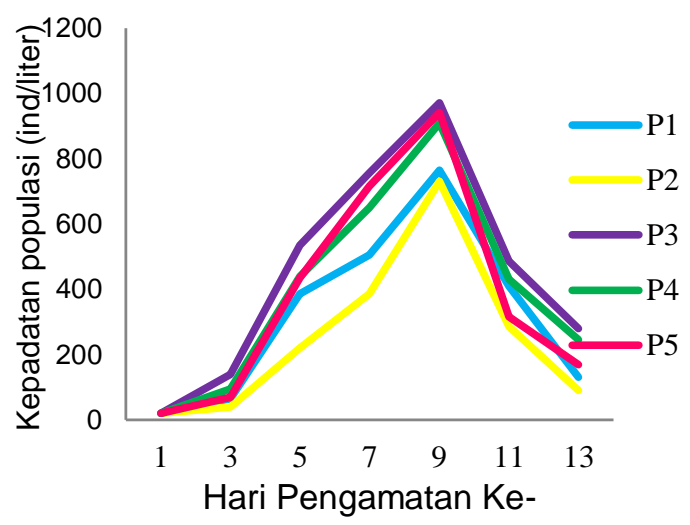

Gambar 1. Kepadatan populasi Daphnia sp. (ind/L) pada berbagai media kultur selama 13 hari pemeliharaan

Namun demikian, kepadatan populasi Daphnia sp. pada hari ke 9 yang tertinggi dimiliki oleh perlakuan ketiga (P3) yaitu media dengan penambahan campuran kotoran ayam dengan dedak padi sebanyak $75 \%$ dan $25 \%$ sedangkan yang terendah dimiliki oleh perlakuan dengan pemberian dedak padi saja $100 \%(p<0,05)$ (Tabel 1).

Tabel 1. Kepadatan puncak populasi Daphnia sp. pada hari ke 9 (ind/L)

\begin{tabular}{crl}
\hline Perlakuan & Rerata \pm Standar Deviasi \\
\hline P 1 & $765 \quad \pm 51,96^{\mathrm{b}}$ \\
P 2 & $730 \quad \pm 49,66^{\mathrm{b}}$ \\
P 3 & $970 \quad \pm 41,63^{\mathrm{a}}$ \\
P 4 & $910 \quad \pm 69,76^{\mathrm{a}}$ \\
P 5 & $940 \quad \pm 36,51^{\mathrm{a}}$ \\
\hline Keterangan: Nilai yang diikuti oleh huruf \\
superskrip yang berbeda \\
menunjukkan berbeda nyata pada \\
uji BNT a 0,05
\end{tabular}

Masing-masing kepadatan pada media yang terdiri dari campuran kotoran ayam dan dedak padi memiliki nilai yang jauh berbeda dibandingkan dengan media kotoran ayam saja atau dedak padi saja. Pada Gambar 1 kepadatan puncak populasi Daphnia sp. terjadi pada hari ke9, diduga karena kandungan nutrisi telah mencukupi untuk meningkatkan pertumbuhan Daphnia sp. Dugaan ini berdasarkan pernyataan Zahidah (2012), bahwa pertumbuhan Daphnia sp. akan meningkat jika ketersediaan pakan tercukupi. Pakan yang dibutuhkan Daphnia sp. adalah berupa bakteri, detritus, protozoa, dan bahan organik tersuspensi. Pertumbuhan bakteri serta detritus, protozoa dan lainnya tergantung dengan penguraian kandungan bahan 
organik pada media tersebut. Dari ke 5 perlakuan tersebut masing-masing bahan organik memiliki total nilai 33,33\% - 68,96 $\%$ (Tabel 2). Menurut Sulasingkin (2003) bahwa jumlah Daphnia sp. dipengaruhi oleh ketersediaan pakan yang sesuai dengan jumlah individu yang berada pada wadah budidaya dan didukung dengan kondisi lingkungan yang baik. Hal ini juga yang diduga terjadi pada media dari ke 5 perlakuan tersebut yang mencapai kondisi baik untuk Daphnia sp. pada hari ke 9 .

Tabel 2. Hasil analisis proksimat media kultur Daphnia sp.

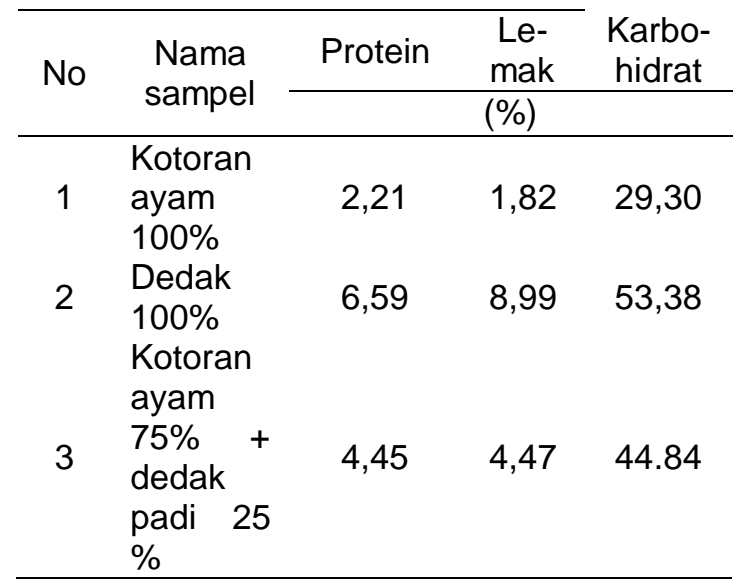

Dari tingkat kepadatan populasi Daphnia $\mathrm{sp}$ dan kandungan protein hasil uji proksimat, media yang menggunakan dedak padi $100 \%$ menunjukkan nilai yang terendah, namun media tersebut memiliki kadar protein yang lebih besar. Hal ini diduga karena protein yang tinggi akan mengakibatkan kadar amoniak yang tinggi (Tabel 4) sebagai hasil penguraian protein yang terjadi di media tersebut selama 9 hari. Faktor lain yang menyebabkan rendahnya populasi pada media 100\% dedak adalah adanya pengendapan dedak yang tidak semua dikonsumsi oleh Daphnia sp. Pengendapan ini terjadi di dasar media yang diduga dapat menjadi racun bagi Daphnia sp. ini. Sebagai akibatnya populasi Daphnia sp. menjadi lebih kecil dibandingkan perlakuan lainnya. Dugaan ini berdasarkan pendapat Radini (2006) yang mengatakan bahwa amoniak merupakan salah satu pemicu stres bagi Daphnia sp. Kadar amoniak dari ke 5 perlakuan dapat dilihat pada Tabel 5. Stres ini selanjutnya menyebabkan Daphnia sp. memproduksi telur yang akhirnya menjadi organisme berjenis kelamin jantan. Selanjutnya populasi Daphnia sp. menjadi turun karena reproduksi tidak dapat dilakukan secara partenogenesis (Kusumaryanto, 1988).

Perlakuan 3 merupakan perlakuan tertinggi pada fase kematian terlihat penurunan rata rata individu dari Tabel 1 dan Tabel 3.

Tabel 3. Kepadatan populasi Daphnia sp. pada hari ke 11 (ind/L)

\begin{tabular}{cc}
\hline Perlakuan & Rerata \pm Standar Deviasi $^{*}$ \\
\hline P 1 & $410 \pm 21.60^{\mathrm{c}}$ \\
P 2 & $285 \pm 61.91^{\mathrm{b}}$ \\
P 3 & $485 \pm 28.87^{\mathrm{a}}$ \\
P 4 & $430 \pm 47.61^{\mathrm{a}}$ \\
P 5 & $315 \pm 30.00^{\mathrm{b}}$
\end{tabular}

Keterangan : * Nilai yang diikuti oleh huruf superskrip yang berbeda menunjukkan berbeda nyata pada uji BNT a 0,05 
Penambahan media kultur hari ke 6 diduga tidak dimanfaatkan sebagai makanan oleh Daphnia sp. justru malah menjadi racun karena terjadi pengendapan sisa pakan di dasar media. Hal ini dapat dilihat pada masing-masing media/wadah kultur, warna air pada media kultur sudah berubah menjadi lebih keruh (Gambar 2).

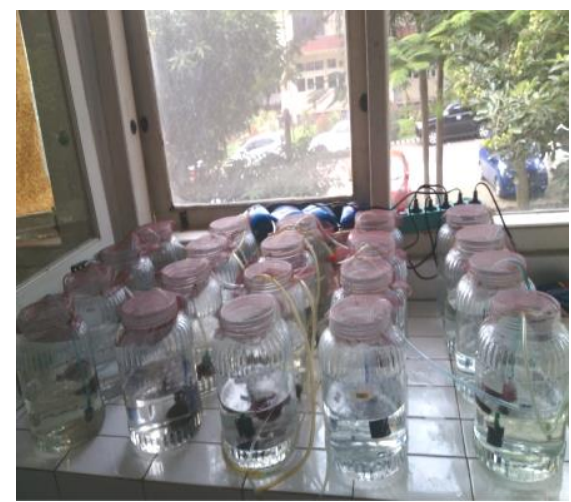

(a)

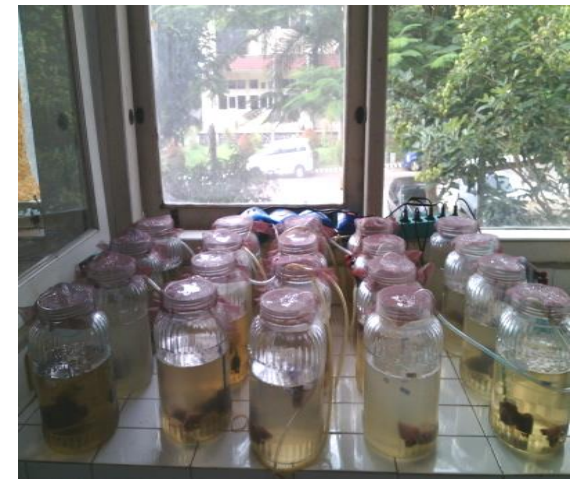

(b)

Gambar 2. Media / wadah kultur pemeliharaan Daphnia sp. di awal penelitian (a) dan di akhir penelitian (b).

Pernyataan tersebut didukung oleh Mubarak (2009), bahwa kandungan amoniak yang beracun dalam media pemeliharaan berasal dari dekomposisi bahan organik. Disamping itu kandungan amoniak yang beracun juga dapat berasal dari sisa hasil metabolisme serta penumpukan pakan yang tidak dimanfaatkan oleh Daphnia sp. Fase kematian disebabkan oleh beberapa faktor di antaranya adalah temperatur tinggi, kurangnya nutrisi dalam perairan, perubahan $\mathrm{pH}$, kontaminasi, serta berkurangnya proses fotosintesis yang dilakukan oleh fitoplankton selain sebagai pakannya juga penghasil oksigen.

Selain itu, faktor lain yang diduga juga berpengaruh terhadap penurunan populasi Daphnia sp. adalah terjadinya persaingan ruang karena populasi Daphnia sp. yang tinggi pada puncak populasi hari ke 9 yaitu 970 ind/l sehingga terjadi persaingan dalam mendapatkan oksigen. Dugaan ini berdasarkan pendapat Prasetiya (2009), yang mengatakan apabila kepadatan Daphnia sp. terlalu tinggi maka aktivitas metabolisme akan meningkat, kandungan amoniak juga akan meningkat, sehingga kebutuhan oksigen juga meningkat.

Selanjutnya dari data hari ke 9 ditentukan laju pertumbuhan Daphnia sp. Berdasarkan hasil penelitian yang telah dilakukan menunjukkan bahwa pemberian pakan yang berbeda mempengaruhi laju pertumbuhan populasi spesifik Daphnia sp. (Tabel 4). 
Tabel 4. Laju pertumbuhan populasi spesifik Daphnia sp.

\begin{tabular}{cc}
\hline Perlakuan & Rerata \pm Standar Deviasi $^{*}$ \\
\hline P 1 & $40,46 \pm 0,73^{\mathrm{b}}$ \\
P 2 & $39,94 \pm 0,75^{\mathrm{b}}$ \\
P 3 & $43,11 \pm 0,47^{\mathrm{a}}$ \\
P 4 & $42,39 \pm 0,82^{\mathrm{a}}$ \\
P 5 & $42,77 \pm 0,43^{\mathrm{a}}$
\end{tabular}

Keterangan : ${ }^{*}$ Nilai yang diikuti oleh huruf superskrip yang berbeda menunjukkan berbeda nyata pada uji BNT a 0,05

Pertumbuhan populasi Daphnia sp. menggunakan media kultur yang berbeda menunjukkan peningkatan yang berbeda setelah mencapai puncak populasi dan menurun dengan rata rata laju pertumbuhan populasi spesifik yang berbeda. Pola pertumbuhan Daphnia sp. dipengaruhi oleh beberapa faktor, antara lain kondisi fisik perairan, jenis pakan, dan konsentrasi pakan. Apabila ketiga faktor tersebut ada, maka laju pertumbuhan Daphnia sp. akan berlangsung lebih cepat dan menghasilkan populasi yang lebih tinggi (Ninuk, 2011).

Laju pertumbuhan spesifik Daphnia sp. pada media dengan kombinasi kotoran ternak dan dedak memiliki nilai yang lebih tinggi dibandingkan dengan pertumbuhan pada media yang menggunakan dedak atau kotoran ternak saja. Perbedaan ini diduga karena kondisi fisik dan kimiawi media tersebut. Sesuai dengan pendapat Hermawan dkk. (2001) bahwa laju pertumbuhan populasi zooplankton banyak dipengaruhi oleh beberapa faktor seperti kandungan nutrisi, suhu, dan aerasi. Selain itu dugaan ini diperkuat oleh Djarijah (1995), sumber energi organisme aquatik diperoleh dari protein, lemak dan karbohidrat. Hasil analisis proksimat yang dilakukan menunjukkan protein yang terkandung pada dedak cukup tinggi dibandingkan dengan kotoran ayam $100 \%$ ataupun dibandingkan dengan kombinasi kotoran ayam 75\% + dedak 25\% (Tabel 2). Sumber energi yang terkandung didalam pakan berupa dedak padi dan kotoran ayam dapat dimanfaatkan bagi pertumbuhan dan perkembangan Daphnia sp.

Kualitas air sangat mempengaruhi pertumbuhan kultur organisme. Hasil pengukuran kualitas air yaitu berupa suhu, $\mathrm{pH}$ dan DO pada media kultur dengan perlakuan yang berbeda dapat dilihat pada Tabel 5. 
Tabel 5. Kualitas air media selama pemeliharaan

\begin{tabular}{|c|c|c|c|c|c|c|c|c|c|c|c|c|}
\hline \multirow{4}{*}{ Perlakuan } & \multicolumn{12}{|c|}{ Parameter Pengamatan } \\
\hline & \multicolumn{3}{|c|}{ Suhu $\left({ }^{\circ} \mathrm{C}\right)$} & \multicolumn{3}{|c|}{$\mathrm{pH}$} & \multicolumn{3}{|c|}{$\mathrm{DO}(\mathrm{mg} / \mathrm{l})$} & \multicolumn{3}{|c|}{ Amoniak (mg/l) } \\
\hline & \multicolumn{3}{|c|}{ Hari ke- } & \multicolumn{3}{|c|}{ Hari ke- } & \multicolumn{3}{|c|}{ Hari ke- } & \multicolumn{3}{|c|}{ Hari ke- } \\
\hline & 1 & 6 & 13 & 1 & 6 & 13 & 1 & 6 & 13 & 1 & 6 & 13 \\
\hline P1 & 28 & 27 & 26 & 7 & $7-8$ & $7-8$ & 5,1 & 5,9 & 6,3 & 0,08 & 0,08 & 0,1 \\
\hline P2 & 28 & 27 & 26 & 7 & $7-8$ & $7-8$ & 5,1 & 5,4 & 6,2 & 0,08 & 0,11 & 0,3 \\
\hline P3 & 28 & 27 & 26 & 7 & $7-8$ & $7-8$ & 5,1 & 5,1 & 6,0 & 0,08 & 0,09 & 0,19 \\
\hline P4 & 28 & 27 & 26 & 7 & $7-8$ & $7-8$ & 5,1 & 5,9 & 6,2 & 0,08 & 0,12 & 0,26 \\
\hline P5 & 28 & 27 & 26 & 7 & $7-8$ & $7-8$ & 5,1 & 5,9 & 6,2 & 0,08 & 0,11 & 0,22 \\
\hline $\begin{array}{l}\text { Standar } \\
\text { kelayakan }\end{array}$ & \multicolumn{3}{|c|}{$\begin{array}{c}22-31^{\circ} \mathrm{C} \\
\text { (Wiadnya, } \\
\text { 1994) }\end{array}$} & \multicolumn{3}{|c|}{$\begin{array}{c}7,1-8,0 \\
\text { (Mokoginta, } \\
2003 \text { ) }\end{array}$} & \multicolumn{3}{|c|}{$\begin{array}{c}>3 \mathrm{mg} / \mathrm{l}(\text { Radini }, \\
2006)\end{array}$} & \multicolumn{3}{|c|}{$\begin{array}{c}<0,2 \mathrm{mg} / \mathrm{l} \\
\text { (Delbare and Dhert } \\
1996)\end{array}$} \\
\hline
\end{tabular}

Seluruh parameter kualitas air, baik suhu, $\mathrm{pH}$, DO serta amoniak untuk seluruh perlakuan masih layak untuk kultur Daphnia sp. Hal ini sesuai dengan pernyataan Wiadnya (1994) bahwa standar kelayakan suhu pada media kultur Daphnia sp. berkisar antara $22-31^{\circ} \mathrm{C}$. Suhu adalah faktor fisika yang dapat mempengaruhi aktifitas dan metabolisme maupun perkembangan organisme. Suhu berpengaruh terhadap proses pertukaran zat metabolisme suatu organisme (Effendi, 2000). Hermawan dkk, (2001) berpendapat bahwa proses pencernaan yang dilakukan oleh Crustaceae berjalan sangat lambat pada suhu rendah, sebaliknya lebih cepat pada suhu media yang hangat.

Derajat keasaman $(\mathrm{pH})$ selama penelitian masih dalam keadaan baik dengan kisaran $\mathrm{pH}$ yaitu 7-7,6 dengan standar kelayakan $\mathrm{pH}$ untuk plankton air tawar 7,1-
8,0 (Mokoginta, 2003). Kadar oksigen yang terlarut (DO) pada masing masing wadah kultur masih berada dalam keadaan baik, yaitu berkisar 5,1-6,3 mg/l dengan standar kelayakan yang baik bagi pertumbuhan Daphnia sp. yaitu $>3 \mathrm{mg} / \mathrm{l}$ (Radini, 2006).

Kadar amoniak akan meningkat seiring dengan meningkatnya suhu dan $\mathrm{pH}$, kadar amoniak yang tinggi dapat menurunkan tingkat reproduksi Daphnia sp. Kadar amoniak pada hari pertama dan hari ke enam masih dalam keadaan baik dengan kisaran 0,08-0,12, tetapi pada hari terakhir (P2), (P4) dan (P5) dengan kadar amoniak 0,3, 0,26, 0,22 $\mathrm{mg} / \mathrm{l}$ melebihi baku mutu yaitu >0,2 mg/l (Delbare and Dhert, 1996). Hal ini diduga karena penumpukan sisa pakan yang tidak dimanfaatkan oleh Daphnia sp. Menurut Mubarak dkk (2009) bahwa amoniak dalam media pemeliharaan berasal dari sisa hasil 
metabolisme serta penumpukan pakan yang tidak termanfaatkan oleh Daphnia sp. Amoniak merupakan salah satu pemicu stres bagi Daphnia sp. karena yang melakukan reproduksi adalah telur mictic sehingga dapat menyebabkan Daphnia sp. memproduksi telur yang berjenis kelamin jantan sehingga populasi Daphnia sp. menjadi turun karena reproduksi tidak terjadi secara partenogenesis (Mubarak, 2009).

\section{Kesimpulan}

Berdasarkan hasil penelitian dapat disimpulkan bahwa kepadatan populasi Daphnia sp. pada pemberian kotoran ayam $75 \%$ + dedak padi $25 \%$ menunjukkan kepadatan populasi tertinggi Daphnia sp. yaitu dengan jumlah 970 ind/L, sedangkan kepadatan populasi terendah dengan pemberian dedak padi $100 \%$ yaitu sebesar 730 ind/l. Media kultur terbaik adalah campuran kotoran ayam $75 \%$ + dedak padi $25 \%$ dengan laju pertumbuhan populasi spesifik tertinggi Daphnia sp. yaitu sebesar 43,11\%/hari. Faktor lingkungan yang paling berpengaruh terhadap pertumbuhan Daphnia sp. adalah peningkatan kadar amonia dalam perairan.

\section{Daftar Pustaka}

Arief, M. A.N. Ratika dan M. Lamid. 2012. Pengaruh Kombinasi Media Bungkil Kelapa Sawit dan Dedak Padi yang Difermentasi Terhadap Produksi Manggot Black Soldier Fly (Hermetia Illucens) Sebagai Sumber Protein Pakan Ikan. Jurnal ilmu perikanan dan Kelautan. 4(1):33-37.

Becker, E. W. 1994. Microalgae Biotechnology and Microbiology. Cambridge University Press. Great Britain England.

Casmuji. 2002. Penggunaan Supernatan Kotoran Ayam dan Tepung Terigu dalam Budidaya Daphnia sp. Skripsi. Program Studi Budidaya Perairan. Fakultas Perikanan dan Ilmu Kelautan. Institut Pertanian Bogor.

Delbare, D and P. Dhert. 1996. Cladocerans, Nematodes and Trocophara Larvae. In Manual on Production and Use of Live Food (P. Lavens and P. Sorgelos, ens).

Djarijah. A.S. 1995. Pakan Alami. Yogyakarta :Kanisius.

Effendi, H. 2003. Telaah Kualitas Air. Kanisius. Yogyakarta. 258 hal.

Hadadi, A. 2004. Pengaruh Pemberian Pakan Tambahan Berbeda Pada Produksi Daphnia sp. di Kolam. Direktorat Jenderal Perikanan Balai Budidaya Air Tawar. Sukabumi

Hartadi, H., S. Reksohadiprodjo dan A.D. Tillman. 1990. Tabel Komposisi Pakan untuk Indonesia. Gajah Mada University Press.

Hermawan, A., Anindiastuti., K.A. Wahyuni dan E. Julianty. 2001. Kajian Pendahuluan Penggunaan Pakan Fermentasi Untuk Kultur Massal Cyclops sp. Buletin Budidaya Laut 13:14-23. 
Makmur, A. 2004. Proses Metabolisme Protein Pakan pada Ikan. Palembang: Balai Riset Perikanan Umum.

Mokoginta, I. 2003. Budidaya Pakan Alami Air Tawar. Modul Daphnia sp. Direktorat Pendidikan Menengah Departemen Pendidikan Nasional. Bidang Budidaya Ikan Program Keahlian Budidaya Ikan Air Tawar.

Mubarak, A.S. 2009. Pemberian Dolomit pada Kultur Daphnia sp. Sistem Daily Feeding Pada Populasi Daphnia sp. dan Kestabilan Kualitas Air. Jurnal IImiah Perikanan dan Kelautan.

Ninuk. 2011. Dinamika Fitoplankton. Indonesian Aquaculture. Tequisa Indonesia.

Jakarta.

Prasetiya.J.D.W.2009. Pemanfaatan Air Buangan Budidaya Lele Dumbo (Clarias gariepinus) sebagai Media Budidaya Daphnia sp. Bandar Lampung: Unila

Radini. D, 2006. Optimasi Suhu, pH Serta Jenis Pakan pada Kultur Daphnia sp. Sekolah Ilmu dan Teknologi Hayat. Bandung.
Rasyaf, M. 1994. Beternak Ayam Pedaging. Penebar Swadaya, Jakarta.

Sayuti. 2003. Budidaya Koki Pengalaman dari Tulung Agung. Agromedia Pustaka. Jakarta.

Subagyo, S.H., 1981. Daur Ulang Limbah Ternak Ayam : Pengaruh Penggunaan Tinja Ayam dalam Ransum Terhadap Penampilan Anak Ayam Remaja Tipe Medium . Fakultas Peternakan, Institut Pertanian Bogor. Bogor.

Sulasingkin, D. 2003. Pengaruh Konsentrasi Ragi yang Berbeda terhadap Pertumbuhan Populasi Daphnia sp. Skripsi. Fakultas Perikanan dan Ilmu Kelautan Institut Pertanian Bogor.

Wiadnya, D. R. 1994. Bahan Kuliah Analisis Laboratorium Kualitas Air. Jurusan PTA. Fakultas Pasca Sarjana. Universitas Brawijaya. Malang.

Zahidah, 2012. Pertumbuhan Populasi Daphnia sp. Yang Diberi Pupuk Limbah Budidaya Karamba Jaraing Apung (KJA) Di Waduk Cirata Yang Telah Difermentasi EM4. Jurnal Akuatika. 